
AUS DER ABTEILUNG FÜR PLASTISCHE-,

HAND- UND WIEDERHERSTELLUNGSCHIRURGIE

(PROF. DR. DR. MED. LUKAS PRANTL)

DER FAKULTÄT FÜR MEDIZIN

DER UNIVERSITÄT REGENSBURG

\title{
PDGF regulated migration of mesenchymal stem cells towards malignancy acts via the PI3K signaling pathway
}

\author{
Inaugural - Dissertation \\ zur Erlangung des Doktorgrades \\ der Medizin
}

der

Fakultät für Medizin

der Universität Regensburg

vorgelegt von

Sonia Salha 
Dekan:

1. Berichterstatter:

2. Berichterstatter:

Tag der mündlichen Prüfung: $\quad 22.10 .2019$ (Regensburg)

24.10.2019 (Zürich) 


\section{Inhaltsverzeichnis}

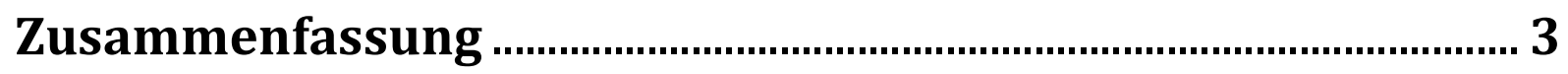

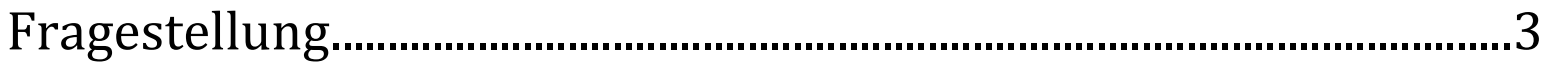

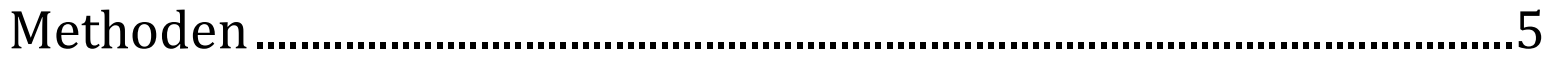

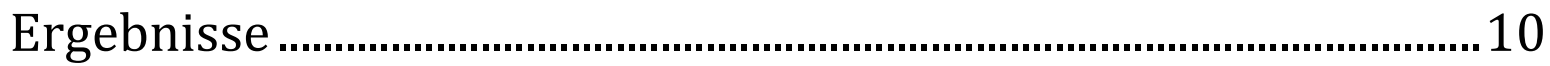

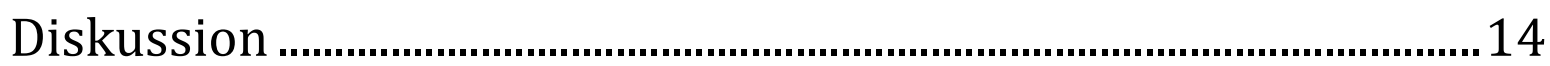

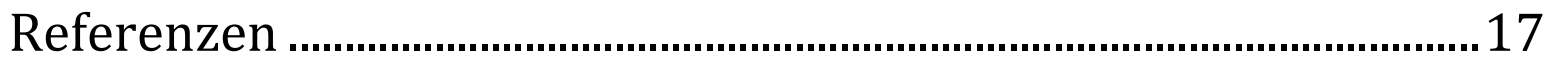

Publikation als Erstautor............................................................... 21

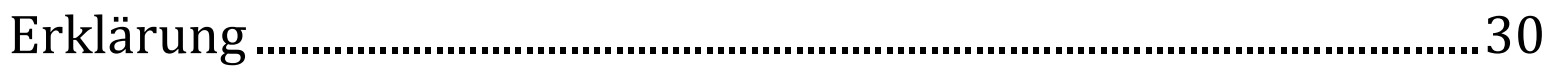

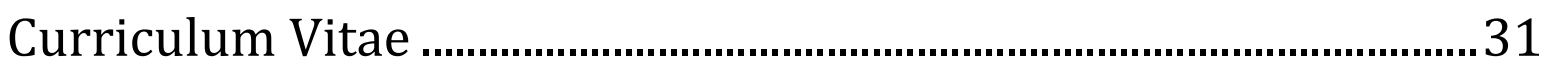




\section{Zusammenfassung}

\section{Fragestellung}

Adulte Stammzellen spielen eine entscheidende Rolle für die Regeneration und Reparation im Rahmen von Verletzungen oder des programmierten Zelltodes (i.e. Apoptose) [1]. In den letzten Jahren konnten in den verschiedensten Geweben multipotente Zellpopulationen nachgewiesen werden, die eine Zelldifferenzierung unter anderem in Knorpelzellen [1], Herz-und Skelettmuskelzellen [2,3] aber auch in neuroektodermale Zellen wie Astrozyten [4,5] oder endodermale Zellen wie Hepatozyten $[6,7]$ zeigten. Es wurde jedoch auch berichtet, dass stromale Zellen von Krebszellen aktiv rekrutiert werden und dadurch ein vermehrtes Tumorwachstum nachgewiesen werden konnte $[8,9]$. Eine große Anzahl von Myo-Fibroblasten sind im Bindegewebe von invasivem Brustkrebs zu finden, welche jedoch nicht im gesunden Brustgewebe vorhanden sind [10]. Es gibt Hinweise, dass diese Cancer-Associated MyoFibroblasten (CAF) von rekrutierten, zirkulierenden Knochenmarksstammzellen abstammen [11,12]. Darüber hinaus gibt es Daten die zeigen, dass auch lokales Fettgewebe der Brust eine Quelle für diese mesenchymale Stammzellen sein kann [13]. Des Weiteren konnte in Brustkrebsmodellen gezeigt werden, dass Mesenchymale Stammzellen (MSC) zum Tumor wandern und sich in dem tumorassoziiertem Stroma integrieren und dabei das Tumorwachstum, die Metastasefähigkeit erhöhen und zur Gefäßneubildung des Tumors beitragen [14-16]. Die Migration von MSC in Richtung von Tumoren wird durch eine große Anzahl verschiedener bioaktiver Moleküle dirigiert (e. g. Wachstumsfaktoren, Cytokine, Chemokine) welche abhängig von der Art der Tumorzellen und deren Nische ist [1720]. Aber auch topographische Mikrostrukturen des Tumorumgebenen Stromas spielen eine Rolle [21] Neuere Untersuchungen deuten darauf hin, dass PDGF von 
Brustkrebszellen einen signifikanten Einfluss auf das Migrationsverhalten von Stammzellen hat [22]. Erst kürzlich konnte gezeigt werden, dass eine Aktivierung des PDGFR- $\beta$ eine entscheidende Rolle bei der Rekrutierung von MSC in Richtung des Tumors spielt [23]. Ausserdem ist bekannt, dass Brustkrebszellen PDGF exprimieren, wobei Strahlentherapeutische Interventionen eine gesteigerte Freisetzung von PDGFB durch Tumorzellen induzieren kann. Dieses zusätzliche PDGF-B kann nicht nur neue MSC in Richtung Tumor dirigieren, sondern auch eine Differenzierung von rekrutierte MSC in Pericyten unterstützen, welche die Gefässneubildung und das Tumorwachstum unterstützt [24].

Durch mehrere Studien wurde belegt, dass korrespondierende Rezeptoren für PDGF Liganden durch MSC exprimiert werden und das die Interaktion von PDGF-BB und PDGFR- $\beta$ in der Gefäßbildung eine entscheide Rolle spielt ist [25-27]. Es konnte unteranderem gezeigt werden, dass während der Gefässneubildung endotheliale Zellen (endothelial cells, ECs) PDGF-BB sezernieren, welches nicht nur die Motilität der Pericyten verstärkt sondern auch einen chemotaktischen Gradienten generiert, der Pericyten rekrutieren kann [28,29]. Darüber hinaus haben erst kürzlich mehrere Studien zeigen können, dass der PDGF-BB Signalweg mit der Remodellierung von Gefässen in Tumoren zusammenhängt und die Expression von transgenem PDGFBB in Tumoren mit einer erhöhten Pericyten Dichte einhergeht [30-32].

Unsere Arbeitsgruppe konnte kürzlich zeigen, dass Fettgewebe multipotente Stammzellen enthält, die in Myo-Fibroblasten transdifferenzieren können, wenn sie dem Einfluss von Tumorzellen produziertem TGF ausgesetzt sind [33]. Dies unterstützt andere Ergebnisse die zeigten, dass a) Pericyten spezifische Marker sowohl in vitro als auch in vivo von ASC (Adipose tissue-derived stem cells) exprimiert werden, b) eine Steigerung der Migration von ASC in vitro durch PDGF-BB erreicht wird, c) ASC eine peri-vaskuläre Morphologie annehmen wenn sie in vivo injiziert werden und d) die 
mikrovaskuläre Densität während der Angiogenese erhöhen indem ASC durch vorhandene Blutgefässe migrieren [34].

Unsere Arbeitsgruppe konnte ausserdem zeigen, dass ASC in Tumorgefässe inkorporiert werden $[15,35]$ und die Differenzierung von Myo-Fibroblasten induzieren können [33]. Allerdings ist bis heute nicht vollständig geklärt durch welche Signalkaskade PDGF-BB an ASCs wirkt und deren Migration reguliert.

In der vorliegenden Arbeit soll untersucht werden, welchen Einfluss die einzelnen IsoFormen von PDGF (PDGF-AA, PDGF-BB, PDGF-CC) auf die Migration von mesenchymalen Stammzellen hat und ob die Signalvermittlung über den ERK1/2 Signalweg allein oder downstream auch von dem mitogen-activated protein kinase (MAPK) Signalweg abhängig ist.

\section{Methoden}

\section{Zelllinien und Zellkultur Techniken}

Murine 4T1 Brustkrebszellen wurden von der Amerikanischen Typ Cultur Collektion (ATCC) gekauft und in RPMI 1640 Medium (Cellgro) kultiviert, wobei sie Supplementierung mit 10\% fetalen Kälberserum (FBS, Atlanta Biologicals), Lglutamine (Cellgro) und Penicillin-Streptomycin (Cellgro) erfolgte. Die Zellkulturen wurden bei $37^{\circ}$ in einem $5 \% \mathrm{CO}_{2}$ Inkubator aufbewahrt.

\section{Isolation von murinen ASCs}

Perirenales, pelvines und subkutanes Fettgewebe wurde von Mäusen (BALB/c) extrahiert und in kleine Stücke zerschnitten [36]. Das Fettgewebe wurde dann mit Blendzyme III (Roche Diagnostics, Basel, Switzerland) $(2 \mathrm{U} / \mathrm{mL})$ für 30 Minuten bei $37^{\circ} \mathrm{C}$ auf einem Rüttler bei 100 rpm inkubiert. Anschließend wurde die Suspension durch einen $100 \mu \mathrm{m}$ Steriflip (Milipore) gefiltert und bei $450 \mathrm{~g}$ für 10 Minuten 
zentrifugiert. Der Überstand wurde verworfen und die Zellen mit 40ml Hanks Balanced Salt Solution (Cellgro) zweimal gewaschen und zentrifugiert. Die Zellen wurden in MEM alpha 1 (Cellgro) mit 20\% FBS, Penicillin (100 U/ml) und $100 \mu \mathrm{g} / \mathrm{ml}$ Streptomycin suspendiert und kultiviert.

\section{ELISA für PDGF-BB}

Serumfreies Medium (RPMI 1640) wurde durch 4T1 über 48 Stunden konditioniert und anschliessend bei $1500 \mathrm{U} / \mathrm{min}$ für 5 Minuten zentrifugiert. Abschliessend wurde der Überstand durch einen $0.45 \mu \mathrm{m}$ Filtersystem (Millipore) geleitet. Das Konditionierte Medium wurde frisch hergestellt und für das Migration Assay benutzt oder bei $-20^{\circ} \mathrm{C}$ für den ELISA Test aufbewahrt. Der ELISA Test wurde mit dem PDGF- BB Quantikine Kit (R\&DSystems) entsprechend der Herstellerangaben durchgeführt.

\section{Überexpression und Inaktivierung von PDGF-B in $4 T 1$ Zellen}

Ein lentiviraler Vektor zur Überexpression von murinen PDGF-B (mPDGF-B/PLVX) wurde durch Klonierung der murinen PDGF-B Sequenz (Invivogen) in den PLVX Leervektor (Clontech) generiert, wobei die Restriktionsenzyme EcoRI und Xbal verwendet wurden. Eine spezifische Kozak Sequenz (GTCGGC) für das PDGF-B Gen wurde dabei vor die Gensequenz eingefügt, um eine höhere Protein Expression in den Zielzellen zu erreichen. Eine Präzisions PCR (high fidelity PCR, Roche) kam dabei mit folgenden Primern zum Einsatz:

sense 3' CTATAAATAAGGAATTCGTCGGCATGAATCGCTGCTGGGCGC 5'; antisense 3' GTTTATATAATCTAGAGGCTCCGAGGGTCTCCTTCAGGGCC 5'

4T1 Zellen wurden mit lentiviralen shRNA Konstrukte (Sigma) infiziert, die als spezifisches Ziel die PDGF-B mRNA hatte und damit die Proteintranslation in der Zielzelle verhinderte, mit konsekutiver Inaktivierung der PDGF-B Sekretion. Ein 
Leervektor des pLVX Konstruktes und unspezifische shRNA Konstrukte wurden verwendet, um entsprechende Kontrollzelllinien zu generieren, welche keine spezifische Veränderung der PDFG-BB Sezernierung zeigten (Figur 1e).
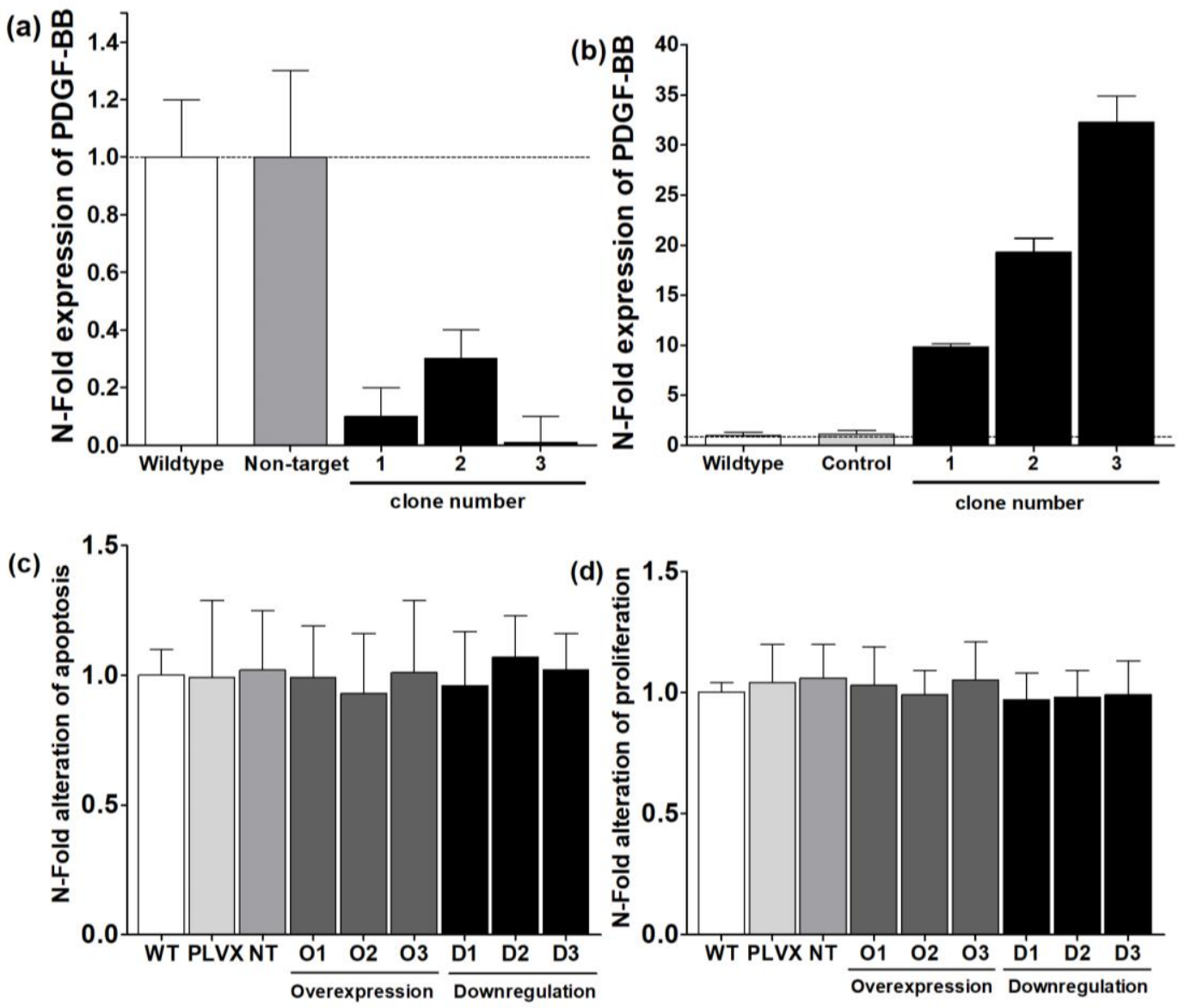

(e)

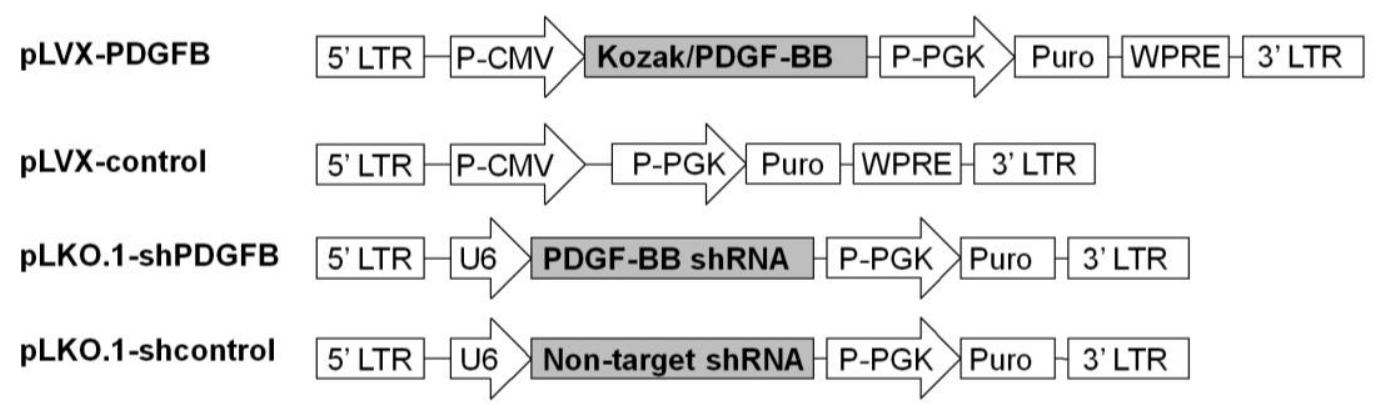

Figur 1: PDGF-BB Protein Gehalt für verschiedene Zellklone nach erfolgreicher lentiviraler Transfektion für die Inaktivierung (a) und Überexpression (b) von PDGF-BB. Es zeigten sich keine signifikanten Unterschiede zwischen den transfizierten Zelllinien und den entsprechenden Kontrollzelllinien bezüglich Apoptose (c) oder Proliferation (d). Lentivirale Konstrukte für die Inaktivierung der PDGF-BB mRNA in Brustkrebszellen basierte auf dem pLKO.1 Vektor wobei die Überexpression von PDGF-BB durch das Klonen einer spezifischen Sequenz in einen pLVX Leervektor erfolgte (e). 


\section{Lentivirale Transfektion}

Lentivirale Vektoren wurden durch die Calcium Phosphate vermittelte Transfektion von 293T Zellen hergestellt wie kürzlich durch unsere Arbeitsgruppe detailliert beschrieben

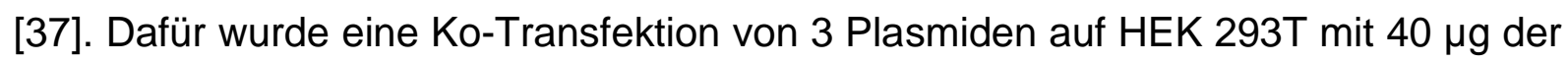
spezifischer Vektor DNA (für die Überexpression oder die Inaktivierung für PDGF-BB), $30 \mu \mathrm{g}$ pCMV- $\triangle \mathrm{R} 8.91$ (The Broad Institute, MA, USA), und $10 \mu \mathrm{g}$ pMD2.G (Addgene, clone 12259) unter Verwendung eines Calcium-Phosphate Transfektion-Kits (Invitrogen) benutzt. Die Lentivirale Vektor Konzentration wurde mit einem p24 ELISA (Cell Biolabs) bestimmt. 4T1 Zellen wurden mit $2.56 \times 10^{5} \mathrm{TU} / \mathrm{ml}$ Virus und Polybrene (8 $\mu \mathrm{g} / \mathrm{ml})$ (Chemicon) infiziert. Nach 8 Stunden wurde das Medium mit frischem DMEM Medium ersetzt. Eine antibiotische Selektion (1.3 $\mu \mathrm{M}$ Puromycin) wurde nach $24 \mathrm{~h}$ für insgesamt 10 Tagen begonnen. Die stabile Überexpression und Inaktivierung von PDGF-BB in Tumorzellen wurde durch einen entsprechenden ELISA (RnD System) bestimmt.

\section{Proliferation und Apoptose Assay}

Die Zellproliferation wurde mit einem Zellproliferations-Kit (Roche) überprüft. Hierzu wurden $1 \times 10^{3}$ lentiviral transfizierte Zellen in 96-Loch Zellkulturplatten gesät, wobei 5 Replikate pro Gruppe verwendet wurden. Den Zellen wurden für 24 Stunden bei 37 inkubiert, um sich auf die Zellkulturplatten festsetzen zu können. Danach wurden die Zellen in frischem Medium für 24 Stunden inkubiert und die Analyse der Zellproliferation nach Herstellerangaben durchgeführt. Die Absorption wurde direkt unter der Verwendung eines Mikroplatten Spektrophotometer (BioTek) durchgeführt. Dabei wurden Messungen bei 492nm (Test Wellenlänge) und zur Korrektur bei 620nm (Referenz Wellenlänge) gemessen. 


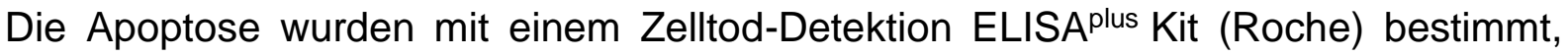
wobei die DNA Fragmentation bestimmt wurde. Alle lentiviral infizierten Zellen wurden dabei in 24-Loch Zellkulturplatten gesät mit einer Konzentration von $1 \times 10^{4} / \mathrm{cm}^{2}$ und bis zur Konfluenz für 72 Stunden inkubiert. Die Zellen wurden von der Zellkulturplatte durch eine Trypsin-EDTA Inkubation gelöst und anschliessend abzentrifugiert. Das Apoptose Assay wurde nach Herstellerangaben durchgeführt. Jeder Ansatz wurde dabei in mindestens 3-facher Repliation durchgeführt. Die Reaktionsprodukte wurden in einem 96-Loch Zellkulturplatte an einem BioTek Mikroplattenleser bestimmt.

\section{Migration Assay}

Ein Transwell Migration System (BD Biosciences) mit einer 3- $\mu$ m Poren Größe wurde für die Migrationsexperimente verwendet. ASC wurden dabei in der oberen Kammer ausgesät. Die Migration von ASC in Richtung PDGF-Isoformen wurde unter Verwendung von rekombinantem PDGF-AA, PDGF-BB und PDGF-CC (RnDSystems) untersucht. Außerdem wurde die Migration gegen Tumorkonditioniertes Medium untersucht, welches in der unteren Kammer vorhanden war. Es wurden zusätzlich LY294002 (Cell Signaling) der ein PI-3 Kinase spezifischer Blocker ist und der ATP Bindungsstelle agiert in einer Endkonzentration von $50 \mu \mathrm{M}$ verwendet. Darüber hinaus wurde PD 98059 (Cell Signaling) verwendet, der ein spezifischer Inhibitor der MAP/ERK Kinase-1 ist und selektiv die ERK MAPK Aktivität inhibiert, ohne dabei einen Effekt auf die Aktivität anderer Serine Threonine Protein Kinasen (wie z.B. Raf1, p38 or JNK MAPK) zu haben. Der Inhibitor wurde mit einer Endkonzentration von $10 \mu \mathrm{M}$ verwendet. Nach $8 \mathrm{~h}$ Migration wurden die Zellen auf der Membran fixiert und mit Calcein gefärbt. Die Zellen wurden nach Fixierung in zufällig gewählten Feldern $(n=3)$ pro Ansatz (N=3) unter einem Fluoreszenz Mikroskop gezählt (Nikon TE-2000U), 
dokumentiert und schließlich mit einer entsprechenden Software ausgewertet (ImageJ)[38]. Unbehandelte Zellen dienten als entsprechende Kontrollen.

Revers Transkription Polymerase Kettenreaktion

Die gesamt RNA wurde unter Verwendung des RNAqueous kit (Ambion) entweder aus der Ursprungszellline oder aus transfizierten Tumorzelllinien extrahiert. Die RNA wurde nachfolgend mittels des iScript ${ }^{\mathrm{TM}}$ cDNA Synthese Kits (Biorad) in copy-DNA zurückgeschrieben. Die Höhe der Konzentration von PDGF-BB und GAPDH mRNA wurde anschliessend mittels Real-Time PCR an einem iCycler (Biorad) unter Verwendung eines SYBRGreen Assays (Applied Biosystem) bestimmt.

\section{Ergebnisse}

Konzentrationsabhängige Migration von ASC

Die PDGF abhängige Migration von ASC wurde in einem in vitro Migrations-Assay untersucht. Dabei zeigte sich eine signifikante Steigerung der Migration von ASC schon bei einer Konzentration von 5ng/ml PDGF-BB, wobei eine Erhöhung der Konzentration ebenfalls mit einer Steigerung der Migration von ASC einherging. Im Gegensatz zeigte PDGF-AA und PDGF-CC nur eine geringe Steigerung der Migration auch bei vielfach höherer Konzentration im Vergleich zu PDGF-BB (Figur 2). 


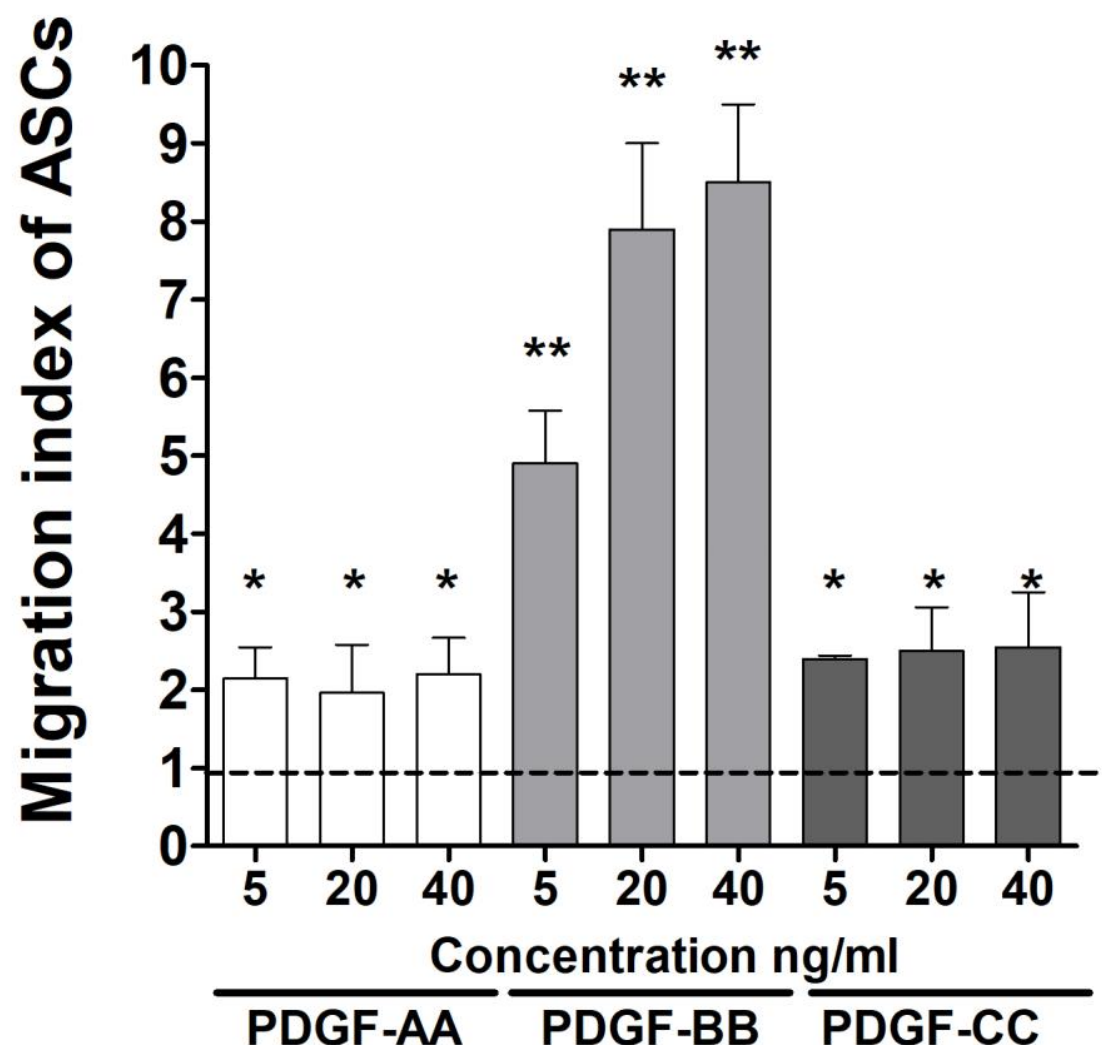

Figur 2: Konzentrationsabhängig zeigte sich nur für PDGF-BB eine signifikante Steigerung der Migration von ASC ( $\left.{ }^{* *} p<0.0001\right)$. Im Gegensatz veränderte sich das Migrationsverhalten von ASC nicht für steigende Konzentrationen von PDGF-AA und PDGF-CC aber zumindest eine signifikante Steigerung zur Kontrollgruppe $\left({ }^{*} p<0.01\right)$. Zusätzliche Steigerung der Migration unter PDGF-AA oder PDGF-CC war nur bei Konzentrationen über $500 \mathrm{ng} / \mathrm{ml}$ möglich (Daten nicht gezeigt).

\section{Inaktivierung und Überexpression von PDGF-BB in Brustkrebszellen}

PDGF-B wurde in der Brustkrebszelllinie (4T1) über-exprimiert oder inaktiviert, in dem entsprechende lentivirale Konstrukte verwendet wurden (Figur 1). Anschliessend wurden Einzelklone gewonnen und in der Kultur expandiert. Die PDGF-BB Expression, die Proliferation und Apoptose der Einzelklone wurde bestimmt und mit der Ausgangszelllinie verglichen. Dabei zeigte sich kein signifikanter Unterschied zwischen den untersuchten Zelllinien bezüglich Apoptose und Proliferation Figur 1c, d). 
Der PI3-Kinase Signalweg

Die Zellmigration konnte signifikant durch PDGFR-a Antikörper blockiert werden, jedoch nur wenn PDGF-AA oder PDGF-CC im Medium verwendet wurden. Im Unterschied dazu zeigte die Blockade des PDGF- $\beta$ Rezeptor eine signifikante Reduzierung der Migration unter PDGF-BB und PDGF-CC Zugabe, nicht jedoch für PDGF-AA. Diese Ergebnisse konnten durch die gemeinsame Blockade der PDGF Rezeptoren mit entsprechendem neutralisierendem Antikörper für PDGF-AA, PDGFBB oder PDGF-CC bestätigt werden (Figur 3a).

Ausserdem konnte nur der PI3K spezifische Inhibitor (LY294002) nicht aber der MAPK Inhibitor (PD98059) eine signifikante Verminderung der Migration der ASC in Richtung der Tumorzellen bewirken (Figur 3b). Die Western Blot Analyse von ASC zeigte eine starke Expression von PDGFR- $\beta$ und nur eine sehr schwache Expression von PDGFR$\alpha$ im Vergleich zu einer entsprechenden Kontrollzellinie (Figur 3c), wie schon in einer früheren Studien von unserer Arbeitsgruppe gezeigt werden konnte [39]. 


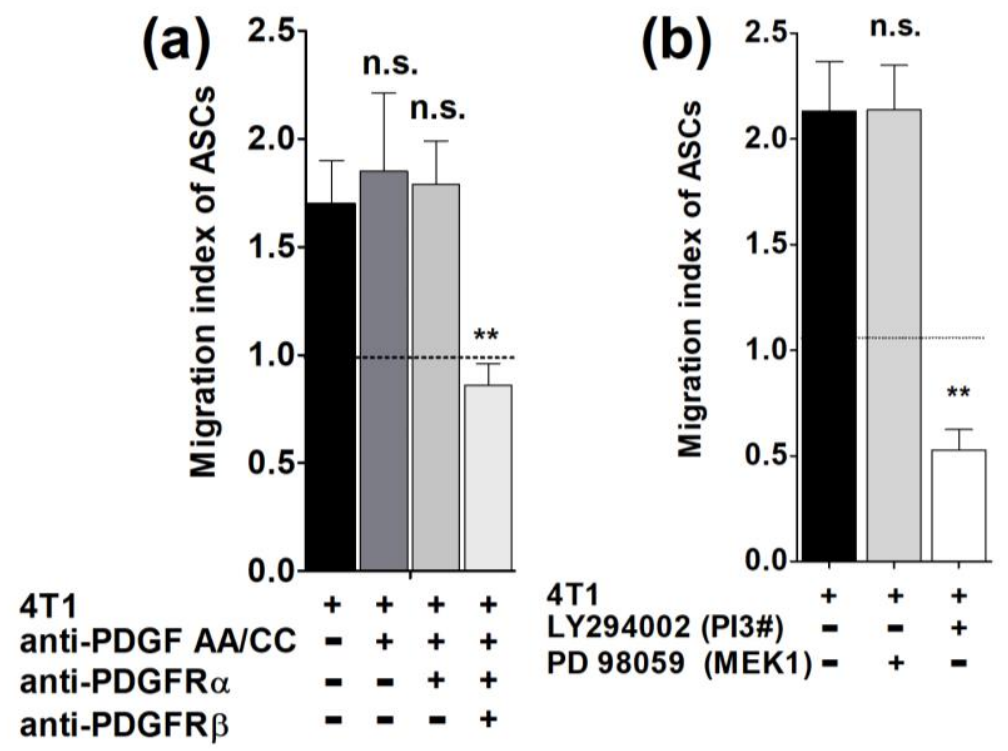

\section{(c) control ASCs}

\section{$175 \mathrm{kDa} \longrightarrow$ PDGFR- $\alpha$

\section{7 kDa}

\section{$\beta$-actin}

Figur 3: (a) Neutralisierende Antikörper gegen PDGF-AA und PDGF-CC zeigten keinen Effekt auf die Migration von ASCs unter gleichzeitiger Blockierung des PDGF- $\alpha$ Rezeptors (n.s., nicht signifikant). Dahingegen zeigte sich eine signifikante Reduktion der Migration von ASC unter Blockierung des PDGF- $\beta$ Rezeptors ( $\left.{ }^{* *} p<0.0001\right)$. (b) Der spezifische PI3K Inhibitor LY294002 konnte die Migration von ASC in Richtung Tumorzell-Medium signifikant reduzieren $\left({ }^{\star \star} p<0.0001\right)$. Im Gegensatz dazu hatte der MAPK Inhibitor (PD98059) keinen Effekt auf die Migration von ASC. (c) Die Western Blot Analyse von ASC zeigte eine starke Expression von des PDGF- $\beta$ Rezeptors and eine nur schwache Expression des PDGF-a Rezeptors im Vergleich zur Kontrollzelllinie (Brustkrebszellen). 


\section{Diskussion}

Die vorliegende Studie zeigt, dass die Migration von ASC hauptsächlich durch PDGFBB über den PI3K Signalweg beeinflusst wird. Die aktuellen Daten belegen, dass der PI3K Signalwege eine entscheidende Rolle für die Migration von ASC in Richtung von Tumoren spielt und daher weiter untersucht werden sollte, um gerade die Tumorprogression in frühen Krankheitsstadium zu verstehen und gegebenenfalls beeinflussen zu können.

Die Rolle von Mesenchymalen Stammzellen bei der Brustkrebserkrankung wird schon seit vielen Jahren untersucht. So konnte zum Beispiel gezeigt werden, dass Stammzellen das Tumorwachstum beeinflussen, die Angiogenese des Tumors unterstützen können und selbst bei dem Prozess der Metastasierung agieren [14-16]. Aktuelle Studien weisen darauf hin, dass Mesenchymale Stammzellen durch Tumore angelockt werden und nachfolgend in Perizyten oder Tumor assoziierte Fibroblasten (Cancer associated fibroblasts, CAFs) transdifferenzieren [15]. Stammzellen akkumulieren im Tumor und in dessen Nähe, wobei sie durch die Sekretion von verschiedenen Chemokinen und Zytokinen (z.B. PDGF) ein entsprechendes Milieu erzeugen, welches das Tumorwachstum begünstigt [40]. In der aktuellen Studie konnten wir zeigen, dass die Migration von ASC in Richtung Tumorzellen eine Konzentrationsabhängigkeit von PDGF-BB zeigt. Ein kürzlich veröffentlichte Studie bestätigt den Zusammenhang der Migration von Stammzellen und Tumor, denn es wurde gezeigt, dass eine Bestrahlung von Brustkrebstumore eine zusätzliche Freisetzung von PDGF-BB zur Folge hatte, die mit einer vermehrten Migration von Stammzellen einherging [41]. Darüber hinaus unterstreicht eine Tierstudie die Bedeutung des PDGF-BBs, da gezeigt werden konnte, dass die Zahl der 
Mesenchymalen Stammzellen in Glioma Tumoren abhängig von der Expression des PDGF-BB war [42].

Die Ergebnisse der vorliegenden Studie zeigen das PDGF-BB der Tumorzellen die Migration von ASC über den PDGF- $\beta$ Rezeptor steuern. Untersuchungen mit neutralisierenden Antikörpern konnten nur einen signifikanten Effekt auf die Migration von ASC bewirken, wenn der PDGF- $\beta$ Rezeptor adressiert wurde. Diese Ergebnisse decken sich mit einer aktuellen Studie bei der der PDGF- $\beta$ Rezeptor auf Progenitorzellen blockiert und dadurch die PDGF-BB induzierte Migration von Mesenchymalen Stammzellen unterbrochen wurde [43]. Darüber hinaus gibt es Studienergebnisse über ein Nuklease-resistentes RNA Aptamer (Gint4.T), welches an die extrazelluläre Domäne des PDGF- $\beta$ Rezeptors bindet und damit die Liganden abhängige Kommunikation zwischen Stammzellen und Tumorzellen sowohl in vitro als auch in vivo unterbrechen konnte [44-46].

Wir haben ausserdem das Downstream Signal des PDGF- $\beta$ Rezeptors untersucht, indem wir einen PI3K spezifischen Inhibitor (LY294002) und einen MAPK spezifischen Inhibitor (PD98059) verwendet haben. Dabei zeigte sich, dass nur die Verwendung des LY294002 mit einer signifikanten Beeinträchtigung der Migration von ASC in Richtung Tumorzellen einherging. Diese Ergebnisse werden durch Experimente unterstützt, die bei einer transgenen Maus mit einer Mutation im PDGF- $\beta$ Rezeptor eine PI3K abhängige Signaltransduktion zeigt [47]. Ausserdem wurde in einer erst kürzlich veröffentlichen Studie berichtet, dass in einem Kolo-rektalen Xenograft Tiermodell Stammzellen das Tumorwachstum und die Tumor-Vaskularisation stimulieren, wobei Akt und ERK in Endothelzellen aktiviert wird und dadurch die Rekrutierung und deren Angiogenese Potential erhöht wird [48].

Durch unsere vorliegende Studie und die in der Literatur vorhandenen Datenlage besteht aktuell kein Zweifel, dass Mesenchymale Stammzellen einen enormen Effekt 
auf das Mikroenvironment von Tumoren bezüglich Angiogenese, Tumorwachstum und Metastasierung hat. Es ist daher von entscheidender Bedeutung, dass die Affinität von Mesenchymalen Stammzellen zu Brustkrebzellen oder anderen Tumorzellen untersucht und verstanden wird, um einen therapeutischen Ansatz zu entwickeln, der das Verhalten von Mesenchymale Stammzellen in diesem Prozess kontrolliert oder beeinflussen kann. 


\section{Referenzen}

[1] Caplan Al. Mesenchymal stem cells. J Orthop Res. 1991;9(5):641-50.

[2] Dezawa M, Ishikawa H, Itokazu Y, Yoshihara T, Hoshino M, Takeda S, et al. Bone marrow stromal cells generate muscle cells and repair muscle degeneration.

Science. 2005;309(5732):314-7.

[3] Kawada H, Fujita J, Kinjo K, Matsuzaki Y, Tsuma M, Miyatake H, et al.

Nonhematopoietic mesenchymal stem cells can be mobilized and differentiate into cardiomyocytes after myocardial infarction. Blood. 2004;104(12):3581-7.

[4] Kopen GC, Prockop DJ, Phinney DG. Marrow stromal cells migrate throughout forebrain and cerebellum, and they differentiate into astrocytes after injection into neonatal mouse brains. Proc Natl Acad Sci USA. 1999;96(19):10711-6.

[5] Sanchez-Ramos J, Song S, Cardozo-Pelaez F, Hazzi C, Stedeford T, Willing A, et al. Adult bone marrow stromal cells differentiate into neural cells in vitro. Exp Neurol. 2000;164(2):247-56.

[6] Chagraoui J, Lepage-Noll A, Anjo A, Uzan G, Charbord P. Fetal liver stroma consists of cells in epithelial-to-mesenchymal transition. Blood. 2003;101(8):297382.

[7] Lee K-D, Kuo TK-C, Whang-Peng J, Chung Y-F, Lin C-T, Chou S-H, et al. In vitro hepatic differentiation of human mesenchymal stem cells. Hepatology. 2004;40(6):1275-84.

[8] Bhowmick NA, Neilson EG, Moses HL. Stromal fibroblasts in cancer initiation and progression. Nature. 2004;432(7015):332-7.

[9] Muehlberg FL, Song Y-H, Krohn A, Pinilla SP, Droll LH, Leng X, et al. Tissueresident stem cells promote breast cancer growth and metastasis. Carcinogenesis. 2009;30(4):589-97.

[10] Sappino AP, Skalli O, Jackson B, Schürch W, Gabbiani G. Smooth-muscle differentiation in stromal cells of malignant and non-malignant breast tissues. Int $\mathrm{J}$ Cancer. 1988;41(5):707-12.

[11] Chauhan $\mathrm{H}$, Abraham A, Phillips JRA, Pringle JH, Walker RA, Jones JL. There is more than one kind of myofibroblast: analysis of CD34 expression in benign, in situ, and invasive breast lesions. J Clin Pathol. 2003;56(4):271-6.

[12] Ishii G, Sangai T, Oda T, Aoyagi Y, Hasebe T, Kanomata N, et al. Bone-marrowderived myofibroblasts contribute to the cancer-induced stromal reaction. Biochem Biophys Res Commun. 2003;309(1):232-40.

[13] Jotzu C, Alt E, Welte G, Li J, Hennessy BT, Devarajan E, et al. Adipose tissue derived stem cells differentiate into carcinoma-associated fibroblast-like cells under the influence of tumor derived factors. Cell Oncol (Dordr). 2011;34(1):55-67. 
[14] Karnoub AE, Dash AB, Vo AP, Sullivan A, Brooks MW, Bell GW, et al. Mesenchymal stem cells within tumour stroma promote breast cancer metastasis. Nature. 2007;449(7162):557-63.

[15] Muehlberg FL, Song Y-H, Krohn A, Pinilla SP, Droll LH, Leng X, et al. Tissueresident stem cells promote breast cancer growth and metastasis. Carcinogenesis. 2009;30(4):589-97.

[16] Kamat P, Schweizer R, Kaenel P, Salemi S, Calcagni M, Giovanoli P, et al. Human Adipose-Derived Mesenchymal Stromal Cells May Promote Breast Cancer Progression and Metastatic Spread. Plast Reconstr Surg. 2015;136(1):76-84.

[17] Lejmi E, Perriraz N, Clément S, Morel P, Baertschiger R, Christofilopoulos P, et al. Inflammatory Chemokines MIP-1 $\delta$ and MIP-3a Are Involved in the Migration of Multipotent Mesenchymal Stromal Cells Induced by Hepatoma Cells. Stem Cells Dev. 2015;24(10):1223-35.

[18] Lourenco S, Teixeira VH, Kalber T, Jose RJ, Floto RA, Janes SM. Macrophage Migration Inhibitory Factor-CXCR4 Is the Dominant Chemotactic Axis in Human Mesenchymal Stem Cell Recruitment to Tumors. The Journal of Immunology. 2015;194(7):3463-74.

[19] Dwyer RM, Potter-Beirne SM, Harrington KA, Lowery AJ, Hennessy E, Murphy $\mathrm{JM}$, et al. Monocyte chemotactic protein-1 secreted by primary breast tumors stimulates migration of mesenchymal stem cells. Clin Cancer Res. 2007;13(17):5020-7.

[20] Johann PD, Müller I. Multipotent Mesenchymal Stromal Cells: Possible Culprits in Solid Tumors? Stem Cells Int. 2015.

[21] Li Z, Xu X, Wang W, Kratz K, Sun X, Zou J, et al. Modulation of the mesenchymal stem cell migration capacity via preconditioning with topographic microstructure. Clin Hemorheol Microcirc. 2017;67(3-4):267-78.

[22] Gehmert S, Gehmert S, Prantl L, Vykoukal J, Alt E, Song Y-H. Breast cancer cells attract the migration of adipose tissue-derived stem cells via the PDGFBB/PDGFR-beta signaling pathway. Biochem Biophys Res Commun. 2010;398(3):601-5.

[23] Ellis SJ, Pines M, Fairchild MJ, Tanentzapf G. In vivo functional analysis reveals specific roles for the integrin-binding sites of talin. J Cell Sci. 2011;124(11):1844-56.

[24] Zhu W, Huang L, Li Y, Zhang X, Gu J, Yan Y, et al. Exosomes derived from human bone marrow mesenchymal stem cells promote tumor growth in vivo. Cancer Lett. 2012;315(1):28-37.

[25] Lindahl P, Johansson BR, Levéen P, Betsholtz C. Pericyte loss and microaneurysm formation in PDGF-B-deficient mice. Science. 1997;277(5323):2425.

[26] Soriano P. Abnormal kidney development and hematological disorders in PDGF beta-receptor mutant mice. Genes Dev. 1994;8(16):1888-96. 
[27] Dwyer RM, Potter-Beirne SM, Harrington KA, Lowery AJ, Hennessy E, Murphy $\mathrm{JM}$, et al. Monocyte chemotactic protein-1 secreted by primary breast tumors stimulates migration of mesenchymal stem cells. Clin Cancer Res.

2007;13(17):5020-7.

[28] Enge M, Bjarnegård M, Gerhardt H, Gustafsson E, Kalén M, Asker N, et al. Endothelium-specific platelet-derived growth factor-B ablation mimics diabetic retinopathy. EMBO J. 2002;21(16):4307-16.

[29] Hellström M, Kalén M, Lindahl P, Abramsson A, Betsholtz C. Role of PDGF-B and PDGFR-beta in recruitment of vascular smooth muscle cells and pericytes during embryonic blood vessel formation in the mouse. Development. 1999;126(14):304755.

[30] Abramsson A, Lindblom P, Betsholtz C. Endothelial and nonendothelial sources of PDGF-B regulate pericyte recruitment and influence vascular pattern formation in tumors. J Clin Invest. 2003;112(8):1142-51.

[31] Furuhashi M, Sjöblom T, Abramsson A, Ellingsen J, Micke P, Li H, et al. Plateletderived growth factor production by B16 melanoma cells leads to increased pericyte abundance in tumors and an associated increase in tumor growth rate. Cancer Res. 2004;64(8):2725-33.

[32] McCarty MF, Somcio RJ, Stoeltzing O, Wey J, Fan F, Liu W, et al. Overexpression of PDGF-BB decreases colorectal and pancreatic cancer growth by increasing tumor pericyte content. J Clin Invest. 2007;117(8):2114-22.

[33] Jotzu C, Alt E, Welte G, Li J, Hennessy BT, Devarajan E, et al. Adipose tissuederived stem cells differentiate into carcinoma-associated fibroblast-like cells under the influence of tumor-derived factors. Anal Cell Pathol (Amst). 2010;33(2):61-79.

[34] Amos PJ, Shang H, Bailey AM, Taylor A, Katz AJ, Peirce SM. IFATS collection: The role of human adipose-derived stromal cells in inflammatory microvascular remodeling and evidence of a perivascular phenotype. Stem Cells.

2008;26(10):2682-90.

[35] Pinilla S, Alt E, Abdul Khalek FJ, Jotzu C, Muehlberg F, Beckmann C, et al. Tissue resident stem cells produce CCL5 under the influence of cancer cells and thereby promote breast cancer cell invasion. Cancer Lett. 2009;284(1):80-5.

[36] Gehmert S, Gehmert S, Prantl L, Vykoukal J, Alt E, Song Y-H. Breast cancer cells attract the migration of adipose tissue-derived stem cells via the PDGFBB/PDGFR-beta signaling pathway. Biochem Biophys Res Commun. 2010;398(3):601-5.

[37] Gehmert S, Wenzel C, Loibl M, Brockhoff G, Huber M, Krutsch W, et al. Adipose tissue-derived stem cell secreted IGF-1 protects myoblasts from the negative effect of myostatin. Biomed Res Int. 2014;2014:129048.

[38] Schneider CA, Rasband WS, Eliceiri KW. NIH Image to ImageJ: 25 years of image analysis. Nat Meth. 2012;9(7):671-5. 
[39] Gehmert S, Gehmert S, Hidayat M, Sultan M, Berner A, Klein S, et al. Angiogenesis: the role of PDGF-BB on adipose-tissue derived stem cells (ASCs). Clin Hemorheol Microcirc. 2011;48(1):5-13.

[40] Nwabo Kamdje AH, Kamga PT, Simo RT, Vecchio L, Seke Etet PF, Muller JM, et al. Mesenchymal stromal cells' role in tumor microenvironment: involvement of signaling pathways. Cancer Biol Med. 2017;14(2):129-41.

[41] Klopp AH, Spaeth EL, Dembinski JL, Woodward WA, Munshi A, Meyn RE, et al. Tumor irradiation increases the recruitment of circulating mesenchymal stem cells into the tumor microenvironment. Cancer Res. 2007;67(24):11687-95.

[42] Hata N, Shinojima N, Gumin J, Yong R, Marini F, Andreeff M, et al. PDGF-BB Mediates the Tropism of Human Mesenchymal Stem Cells for Malignant Gliomas. Neurosurgery. 2010;66(1):144-57.

[43] Fiedler J, Etzel N, Brenner RE. To go or not to go: Migration of human mesenchymal progenitor cells stimulated by isoforms of PDGF. J Cell Biochem. 2004;93(5):990-8.

[44] Camorani S, Hill BS, Fontanella R, Greco A, Gramanzini M, Auletta L, et al. Inhibition of Bone Marrow-Derived Mesenchymal Stem Cells Homing Towards TripleNegative Breast Cancer Microenvironment Using an Anti-PDGFR $\beta$ Aptamer. Theranostics. 2017;7(14):3595-607.

[45] Camorani S, Esposito CL, Rienzo A, Catuogno S, laboni M, Condorelli G, et al. Inhibition of receptor signaling and of glioblastoma-derived tumor growth by a novel PDGFR $\beta$ aptamer. Mol Ther. 2014;22(4):828-41.

[46] Monaco I, Camorani S, Colecchia D, Locatelli E, Calandro P, Oudin A, et al. Aptamer Functionalization of Nanosystems for Glioblastoma Targeting through the Blood-Brain Barrier. J Med Chem. 2017;60(10):4510-6.

[47] Rodt SA, Ahlén K, Berg A, Rubin K, Reed RK. A novel physiological function for platelet-derived growth factor-BB in rat dermis. J Physiol. 1996;495(Pt 1):193-200.

[48] Huang W-H, Chang M-C, Tsai K-S, Hung M-C, Chen H-L, Hung S-C. Mesenchymal stem cells promote growth and angiogenesis of tumors in mice. Oncogene. 2013;32(37):4343-54. 


\title{
PDGF regulated migration of mesenchymal stem cells towards malignancy acts via the PI3K signaling pathway
}

\author{
Sonia Salha ${ }^{\mathrm{a}, \mathrm{c}}$, Sebastian Gehmert ${ }^{\mathrm{b}, \mathrm{c}, *}$, Vanessa Brébant ${ }^{\mathrm{c}, \mathrm{d}}$, Alexandra Anker ${ }^{\mathrm{c}, \mathrm{d}}$, \\ Markus Loibl ${ }^{\mathrm{c}, \mathrm{e}}$, Lukas Prantl ${ }^{\mathrm{c}, \mathrm{d}}$ and Sanga Gehmert ${ }^{\mathrm{c}, \mathrm{f}}$ \\ ${ }^{a}$ Department of Orthopedics and Traumatology, University Hospital Basel, Switzerland \\ ${ }^{\mathrm{b}}$ Department of Orthopedics, University Children's Hospital Basel, Switzerland \\ ${ }^{\mathrm{c}}$ Applied Stem Cell Research Center, University Medical Center Regensburg, Germany \\ ${ }^{\mathrm{d}}$ Department of Plastic, Hand-and Reconstructive Surgery, University Medical Center Regensburg, \\ Germany \\ ${ }^{\mathrm{e}}$ Department of Trauma Surgery, Regensburg University Medical Center, Regensburg, Germany \\ ${ }^{\mathrm{f}}$ Department of Gynecology and Obstetrics, Kantonsspital Baselland, Liestal, Switzerland
}

\begin{abstract}
.
INTRODUCTION: Mesenchymal stem cells (MSCs) have been described in breast cancer models to migrate towards carcinoma and integrate into tumor associated stroma supporting tumor growth, increasing their metastatic potency and contributing to tumor-angiogenesis. Platelet-derived growth factor (PDGF) isoforms (AA, BB, CC) stimulate growth, survival and motility of MSCs and certain other cell types. Noteworthy, breast carcinomas are known to express PDGF. We aim to further shed light on i) the relevance of the different PDGF isoforms on adipose tissue derived stem cells (ASCs) migration and ii) the underlying pathway dependent on PDGF stimulation.

MATERIALS AND METHODS: Breast cancer cell lines were purchased and ASC's were isolated from murine subcutaneous adipose tissue. The transmigration of ASC's towards the PDGF-isoforms was assessed by using recombinant human PDGF-AA, PDGF-BB and PDGF-CC in a trans-well culture dish system. Transmigrated ASC's were quantified in 5 randomly selected fields per condition using fluorescence microscopy after calcein-staining. PDGF-BB depended transmigration of ASC's was verified by downregulation and overexpression of PDGF-BB in breast cancer cell line using lentiviral vectors. In addition, a PI3-kinase inhibitor (LY294002) and a MAP-kinase inhibitor (PD98059) were used to identify the pathway involved in the PDGF-BB mediated migration of ASC's towards tumor.

RESULTS: ASC's transmigration significantly increased towards PDGF AA at $50 \mathrm{ng}$ and only showed further increase by $500 \mathrm{ng}$ which was similar to cell behavior when exposed to PDGF CC. In comparison, PDGF-BB significantly increased ASC's transmigration already at a low level of $5 \mathrm{ng}$ with further significant increase for $20 \mathrm{ng}$ and $40 \mathrm{ng}$. Cell transmigration was blocked with PDGFR- $\alpha$ antibodies but only for PDGF-AA and PDGF-CC whereas PDGFR- $\beta$ blockage showed a significant effect on transmigration for PDGF-BB and PDGF-CC but not for PDGF-AA. Neutralizing antibodies in combination with PDGF receptor blockage confirmed findings. In addition, only PI3-kinase inhibitor but not the MEK-1 selective inhibitor caused a significant decrease of transmigration for ASCs towards breast cancer cells.

DISCUSSION: The transmigration of ASC's is most significantly enhanced by PDGF-BB via the PI3-kinase pathway. This data support that PI3-kinase is an important key player for MSC migration towards malignancy which need further research to prevent tumor progression in early disease stage.
\end{abstract}

Keywords: Mesenchymal stem cells, migration, breast cancer, PDGF-BB, PI3K pathway

\footnotetext{
*Corresponding author: Sebastian Gehmert, Department of Orthopedics, University Children's Hospital Basel, Spitalstrasse 33, 4031 Basel, Switzerland. E-mail: s.gehmert@gmail.com.
} 


\section{Introduction}

Mesenchymal stem cells (MSCs) have been identified in various tissue which resides as pericytes within the basement membrane of small vessels with direct cellular contact to endothelial cells [1]. Moreover, MSCs have been described in breast cancer models to migrate towards carcinoma and integrate into tumor associated stroma supporting tumor growth, increasing their metastatic potency and contributing to tumor-angiogenesis [2-4]. The migration of MSCs towards malignancy is directed by a large variety of bioactive molecules (e.g. growth factors, cytokines, chemokines) but also by topographic microstructure of the environement [5] however, the type of cytokine released is dependent on the tumor cell type and its niche [6-9].

Recently, it has been reported that PDGFR- $\beta$ signaling plays an important role in recruitment of MSCs towards tumor sites [10]. Noteworthy, breast cancer cells are known to express PDGF and radiation therapy has been shown to increase the release of PDGF-B by tumor cells, which not only attract MSCs to the tumor site but also induces the newly recruited MSC to differentiate into pericytes, and promote vasculogenesis and tumor growth [11]. In addition, it has been confirmed that MSCs express the corresponding receptors for PDGF ligands [8]. The essential role of PDGF-BB/PDGFR- $\beta$ signaling in vascular maturation has been well-documented by genetic studies $[12,13]$. During vascular development, endothelial cells (ECs) secrete PDGF-BB, which not only enhances pericyte motility but also forms a chemotaxis-like gradient to facilitate pericyte recruitment $[14,15]$. Recently, several studies have correlated PDGF-BB signaling with vascular remodeling within tumors and showed that transgenic PDGF-BB expression in tumors can increase pericyte [16-18].

We have recently shown that adipose tissue contains multipotent stem cells that can differentiate into myofibroblasts when exposed to tumor cell derived TGF [19]. Amos et al. [20] demonstrated that adipose tissue-derived stem cells (ASCs) express pericyte lineage markers in vivo and in vitro, exhibit increased migration in response to PDGF-BB in vitro, reveal perivascular morphology when injected in vivo, and contribute to increases in microvascular density during angiogenesis by migrating toward vessels. We have shown that ASCs are incorporated into tumor vessels [3,21] and are capable of inducing myofibroblast differentiation [19]. However, to date it is not clear by which pathway PDGF-BB acts on ASCs and regulates their migration.

In the present study we aim to further shed light on i) the relevance of the different PDGF isoforms on ASCs migration and ii) the underlying pathway dependent on PDGF stimulation.

\section{Materials and methods}

\subsection{Cell lines and cell culture techniques}

4T1 murine breast cancer cells were purchased from American Type Culture Collection (ATCC) and cultured in RPMI 1640 medium (Cellgro) supplemented with 10\% fetal bovine serum (FBS) (Atlanta Biologicals), L-glutamine (Cellgro), and penicillin-streptomycin (Cellgro) at $37^{\circ} \mathrm{C}$ in a $5 \%$ $\mathrm{CO}_{2}$-containing chamber.

\subsection{Isolation of murine ASCs}

Perirenal, pelvine, and subcutaneous fat tissues were dissected from mice and processed as described previously [22]. 


\subsection{ELISAs for PDGF-BB}

Serumfree media (RPMI 1640) were conditioned by $4 \mathrm{~T} 1$ for 48 hours, centrifuged at $1500 \mathrm{rpm}$ for $5 \mathrm{~min}$ and passed through a $0.45 \mu \mathrm{m}$ filter system (Millipore). Conditioned media (CM) were prepared fresh and used immediately for migration assay or stored at $-20^{\circ} \mathrm{C}$ for ELISA. ELISAs were performed using the PDGF-BB Quantikine Kit (R\&DSystems) according to the manufacturer's instructions.

\subsection{Overexpressing and silencing of PDGF-B in $4 T 1$ cell line}

A lentiviral vector overexpressing the murine PDGF-B (mPDGF-B/PLVX) was constructed by subcloning murine PDGF-B (Invivogen) into the PLVX vector (Clontech) between EcoRI and XbaI restriction. A specific Kozak sequence for the PDGF-B gene (GTCGGC) was inserted in front of the gene to achieve a higher protein expression in target cell lines. High fidelity PCR (Roche) and following primer were used:

sense 3' CTATAAATAAGGAATTCGTCGGCATGAATCGCTGCTGGGCGC 5';

antisense 3' GTTTATATAATCTAGAGGCTCCGAGGGTCTCCTTCAGGGCC 5'

4T1 cell lines were infected with lentiviral shRNA constructs (Sigma) targeting PDGF-B mRNA to silence secretion of PDGF-B. An empty pLVX and non-target shRNA were used to establish control cell lines with no interference of PDGF-BB secretion (Fig. 1e).

\subsection{Lentiviral transfection}

Lentiviral vectors were generated by calcium phosphate-mediated transfection of 293T cells as described previously by our group [23].

4T1 cells were infected with the appropriate lentiviral construct and selected by puromycin for 10 days. ELISA for murine PDGF-B (RnDSystems) was used to measure the level of PDGF-B in 4T1 overexpressing or downregulation this specific protein (Fig. 1a, b).

\subsection{Proliferation and apoptosis assay}

Cell proliferation was monitored using Cell Proliferation Reagent Kit I (Roche). $1 \times 10^{3}$ lentiviral transfected cells were seeded in quintuplicates into each well of a 96 well plate and allowed to attach for a period of $24 \mathrm{~h}$ at $37{ }^{\circ} \mathrm{C}$. Afterwards, cells were incubated in fresh applied cell medium for $24 \mathrm{~h}$. Analysis of proliferation was carried out following the kit instruction. Absorbance was measured immediately using a microplate reader spectrophotometer (BioTek). Measurements were performed at $492 \mathrm{~nm}$ (test wavelength) and at $620 \mathrm{~nm}$ (reference wavelength), to correct for noise.

Apoptosis was investigated by using Cell Death Detection ELISA ${ }^{\text {plus }}$ (Roche), which monitors DNA fragmentation. All lentiviral infected cell clones were seeded into 24 well plates at $1 \times 10^{4} / \mathrm{cm}^{2}$ and grown to confluency for $72 \mathrm{~h}$. Cells were harvested using trypsin-EDTA. Cell pellets were collected and apoptosis assays were performed according to the manufacture protocol. Each experimental condition was carried out with at least three samples and was repeated at least three times. The reaction products in each 96-well plate were read using a BioTek microplate reader.

\subsection{Transmigration assay}

The Transwell Migration System (BD Biosciences) with a 3- $\mu \mathrm{m}$ pore size was used for the transmigration experiments. Murine ASCs were plated in the upper chamber of the system. The transmigration of ACS's towards the PDGF-isoforms was assessed by using recombinant PDGF-AA, PDGF-BB and 
(a)

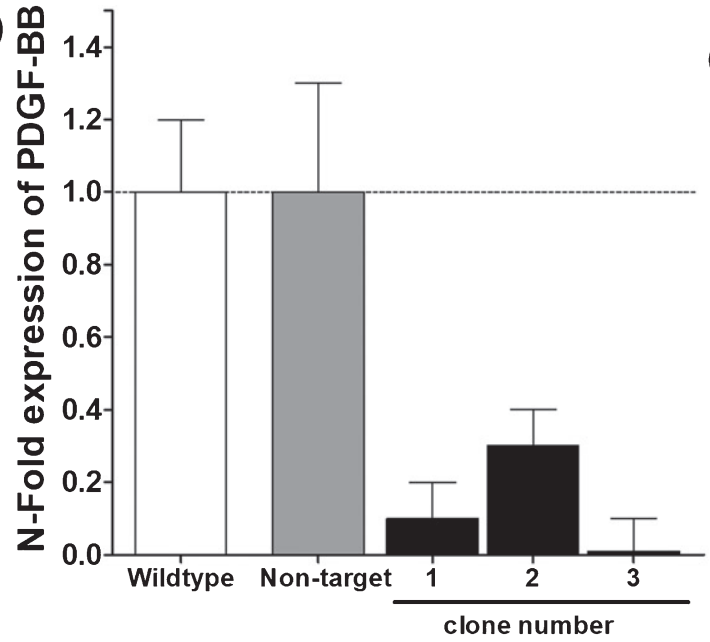

(c)

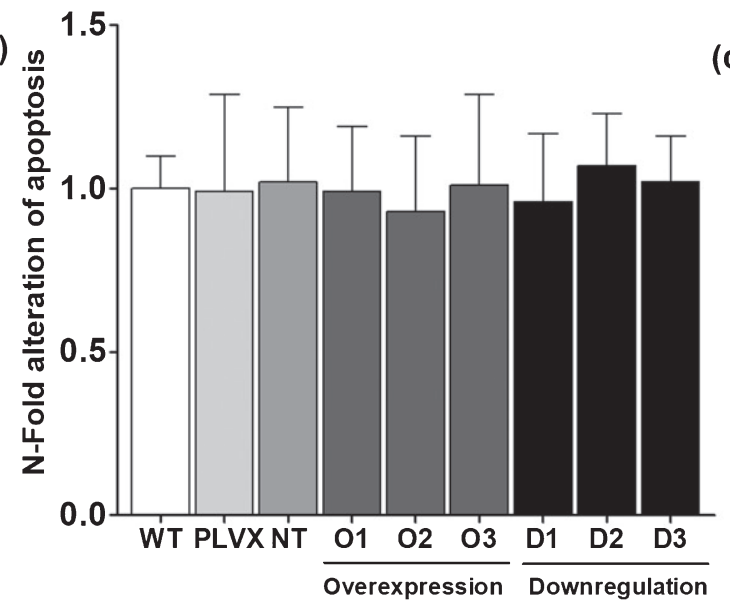

(b)

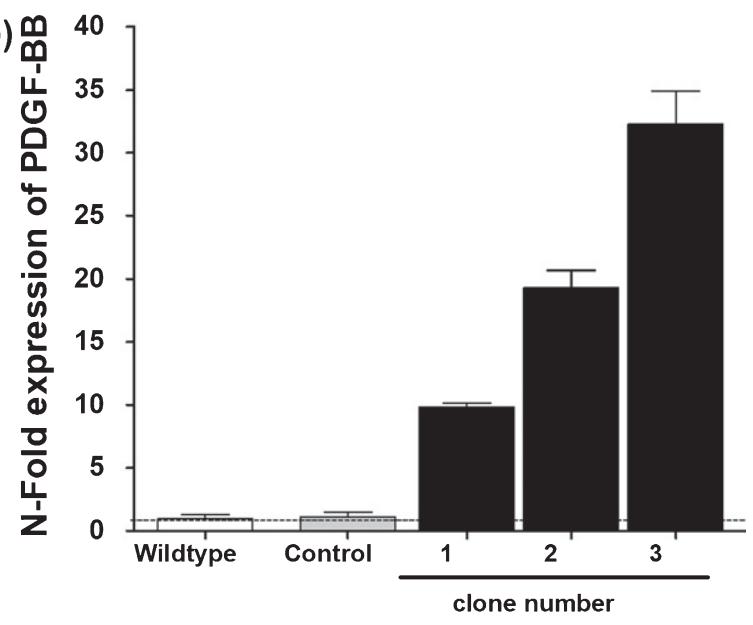

(d)

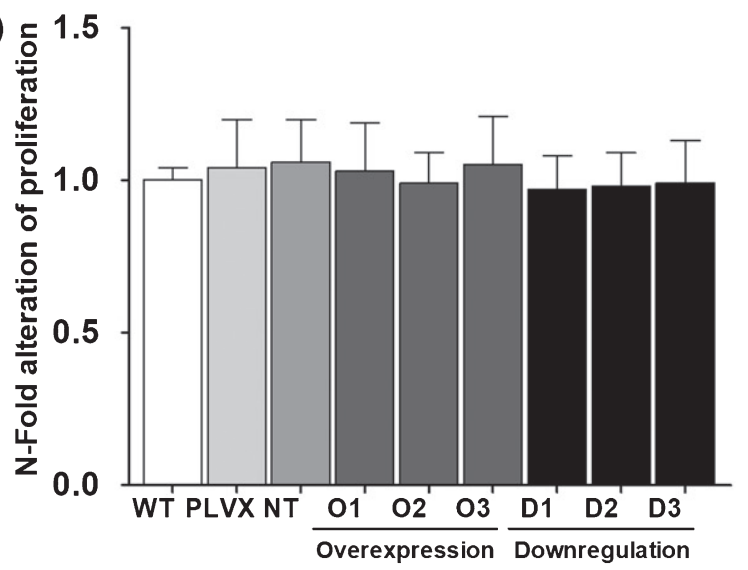

(e)

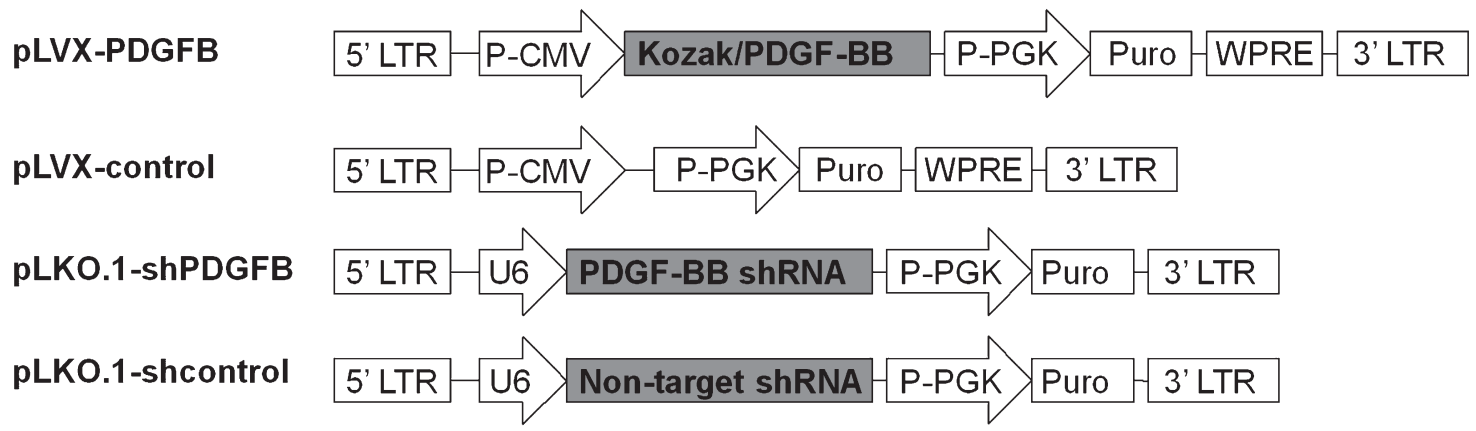

Fig. 1. PDGF-BB protein levels for different clones after successful lentiviral transfection for downregulation (a) and overexpressing (b) of PDGF-BB. No significant difference was evident between transfected clones and appropriate controls regarding apoptosis (c) or proliferation (d). Lentiviral construct for silencing of PDGF-BB mRNA in breast cancer cells was based on a pLKO.1 vector whereas overexpression of PDGF-BB was achieved by cloning the appropriate sequence into a pLVX backbone (e). 
PDGF-CC (RnDSystems) in a trans-well culture dish system. After $8 \mathrm{~h}$ of transmigration through the membrane, cells were fixed and stained with calcein (Sigma). Migrated cells were quantified in randomly selected fields $(n=3)$ per condition (triplicate, $n=3$ ) using fluorescence microscope (Nikon TE-2000U) with a Cascade camera (Photometrics) and Image J software [24].

\subsection{Inhibitor assay}

Commercially available Inhibitors of PI3-kinase (PI3K) and MAP kinase (MAPK) were used to identify the pathways involved in the PDGF-BB mediated migration of ASCs towards breast cancer cells. PI3K/Akt signaling was inhibited by LY294002 (Cell Signaling) at a final concentration of $50 \mu \mathrm{M}$ and MAPK signaling was inhibited by PD98059 (Cell Signaling) at a final concentration of $10 \mu \mathrm{M}$. ASCs were incubated in culture medium containing the inhibitor for $48 \mathrm{~h}$ prior to migration assay and the inhibitors remained in the culture medium during the subsequent transmigration assay. Untreated cells served as control.

\subsection{Reverse transcription-polymerase chain reaction}

Total RNA was extracted from parental and transfected cancer cell line using RNAqueous kit (Ambion) and was reverse transcribed using iScript ${ }^{\mathrm{TM}} \mathrm{cDNA}$ synthesis kit (Biorad). Expression level of PDGF-BB and GAPDH mRNA was determined by real-time PCR on an iCycler (Biorad) using SYBRGreen assay (Applied Biosystem) and data were analyzed as previously described [2].

\section{Results}

\subsection{Dose dependent migration of ASCs}

To characterize the PDGF dependent migration of ASCs, different members of the PDGF family were used for in vitro migration assay. Transmigration of ASCs significantly increased for recombinant PDGF-BB at a concentration of $5 \mathrm{ng} / \mathrm{ml}$ and further increased over a small range of protein concentration in a dose dependent manner (Fig. 2). In contrast, transmigration of ASCs only showed a 2-fold increase of migration index for PDGF-AA or PDGF-CC at the same range of protein concentration as apparent for PDDG-BB. Further increase of transmigration was only evident for protein concentration of PDGF-AA and PDGF-CC at $500 \mathrm{ng} / \mathrm{ml}$ (data not shown).

\subsection{Silencing and overexpression of PDGF-BB in breast cancer cell line}

PDGF-B was over expressed or downregulated in breast cancer cell line (4T1) using lentiviral constructs (Fig. 1), and single clones were picked, grown to culture and investigated for PDGF-BB expression, proliferation and apoptosis in comparison to the parental cell line. PDGF-BB silencing or overexpression revealed no significant difference regarding apoptosis or proliferation when compared to control transfected or non-transfected cell lines (Fig. 1c, d).

\subsection{PI3-Kinase pathway}

Cell transmigration was blocked with PDGFR- $\alpha$ antibodies but only for PDGF-AA and PDGF-CC whereas PDGFR- $\beta$ blockage showed a significant effect on transmigration for PDGF-BB and PDGF- 


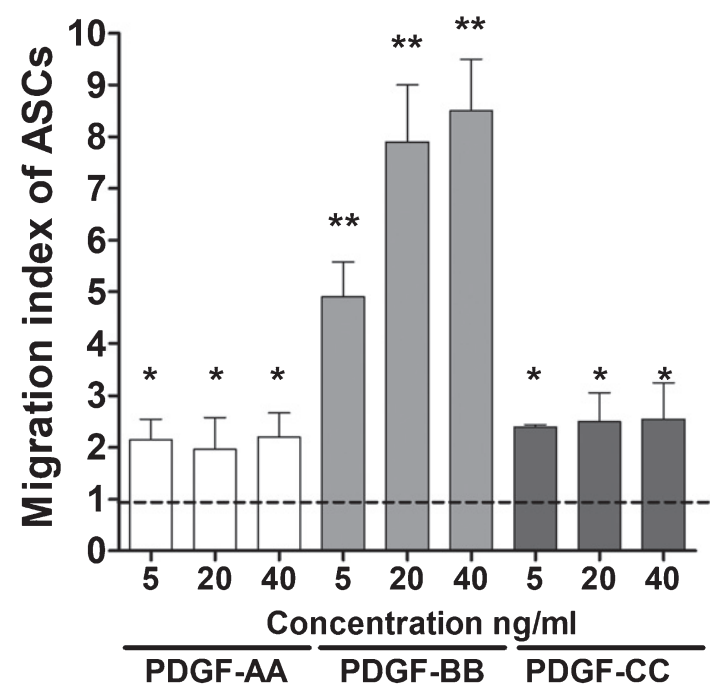

Fig. 2. Dose dependent transmigration of ASCs was only evident for PDGF-BB and showed a significant increase for all applied concentrations $(* * \mathrm{p}<0.0001)$. In contrast, increased concentration of PDGF-AA and PDGF-CC did not show any variation of ASCs transmigration capacity as seen for PDGF-BB concentration $(5 \mathrm{ng} / \mathrm{ml}$ to $40 \mathrm{ng} / \mathrm{ml})$ but a significant increase of transmigration when compared to control $(* \mathrm{p}<0.01)$. However, a further increase of transmigration was only apparent for concentration higher than $500 \mathrm{ng} / \mathrm{ml}$ (data not shown).

CC but not for PDGF-AA. Neutralizing antibodies in combination with PDGF receptor blockage confirmed findings (Fig. 3a).

In addition, only PI3K inhibitor (LY294002) but not the MAPK inhibitor (PD98059) was associated with a significant decrease of transmigration for ASCs towards breast cancer cells (Fig. 3b). Western blot analyses of ASCs revealed strong expression of PDGFR- $\beta$ and only weak expression of PDGFR- $\alpha$ when compared with control cell line (Fig. 3c) as previously reported by our group [25].

\section{Discussion}

The current study shows that the transmigration of ASCs is most significantly enhanced by PDGF$\mathrm{BB}$ via the PI3K pathway. Our data support that PI3K is an important key player for ASCs migration towards malignancy which need further research to prevent tumor progression in early disease stage.

The role of MSCs in breast cancer has been the focus of research for many years. It has been shown, that MSCs enhance tumor growth and are able to support tumor angiogenesis and the process of metastases [2-4]. Recent studies suggest that MSCs are attracted to tumor site and subsequently differentiate into pericytes or cancer associated fibroblasts [3]. MSCs accumulate at the sites of tumor and establish a microenvironment supporting growth by secreting various chemokines and cytokines (e. g. PDGF) [26]. We could show, that transmigration of ASCs towards breast cancer is especially dose dependent by breast cancer secreted PDGF-BB. A recent study strengthened the link between migration of MSCs and tumor by showing that the irradiation of breast cancer enhanced the release of PDGF-BB by cancer cells which caused enhanced migration of MSCs towards the tumor [27]. In addition, an animal study underline the importance of PDGF-BB mediated tropism of MSCs towards malignancy showing that MSCs localized significantly more to high expressing PDGF-BB gliomas [28].

Our results indicate that tumor-derived PDGF-BB mediates migration of ASCs through PDGFR$\beta$ which is expressed on ASCs. Pretreatment of ASCs with neutralizing antibodies reduced in vitro 

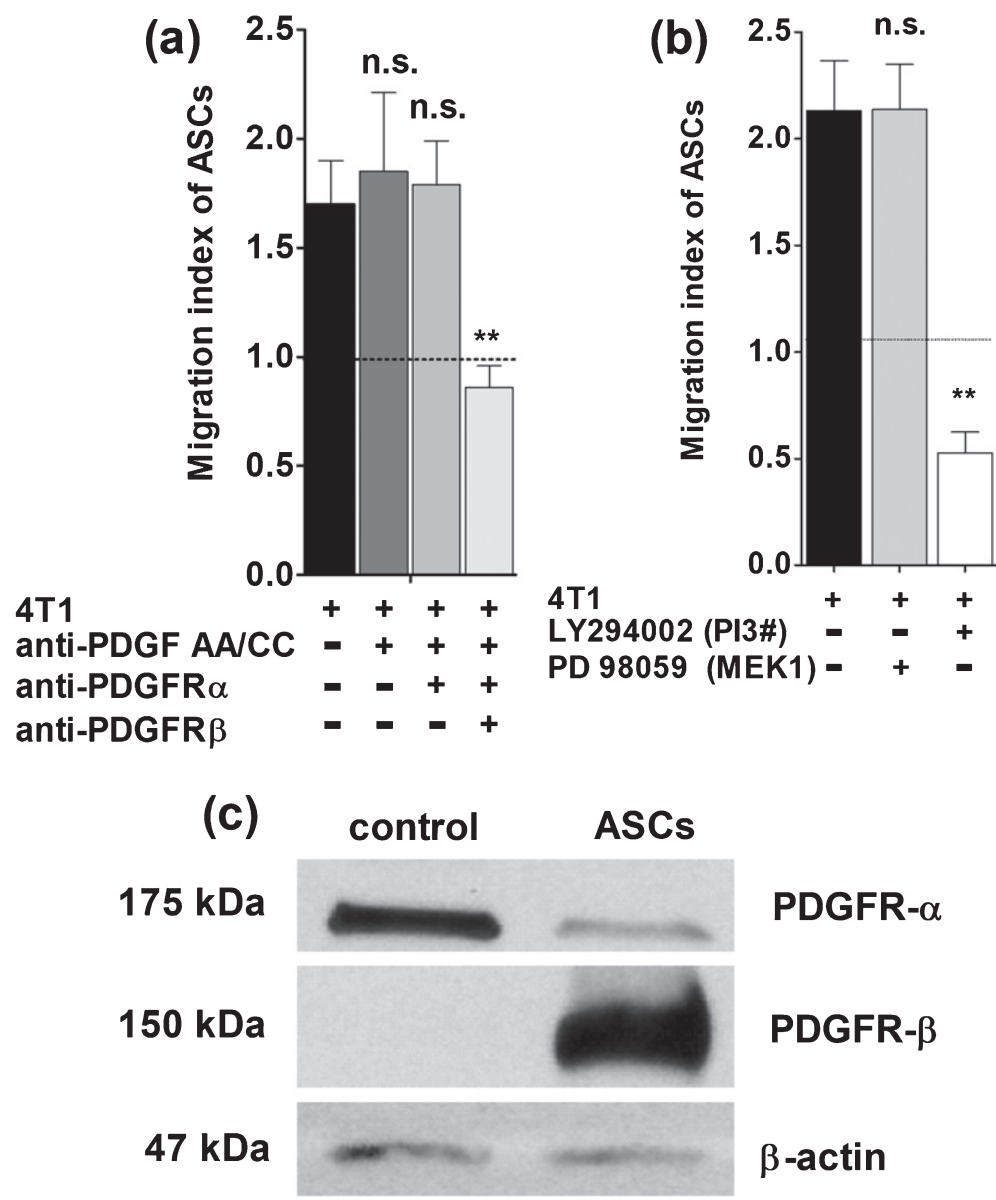

Fig. 3. (a) Neutralizing antibodies against PDGF-AA und PDGF-CC did not affect transmigration of ASCs even when PDGFR- $\alpha$ was blocked (n.s., non-significant). However, significant decrease of ASCs transmigration was apparent when PDGFR-beta was blocked (**p<0.0001). (b) LY294002 targets PI3K and resulted in a significant decrease of ASCs transmigration towards breast cancer conditioned medium $(* * \mathrm{p}<0.0001)$. In contrast, the selective inhibitor of MAPK (PD98059) did not interfere with transmigration of ASCs. (c) Western blot analyses of ASCs revealed strong expression of PDGFR- $\beta$ and only weak expression of PDGFR- $\alpha$ when compared with control cell line (breast cancer cell line).

migration of ASCs only when PDGFR- $\beta$ was targeted. This is in line with a recent report showing that blocking of PDGFR- $\beta$ on progenitor cells abolished PDGF-BB induced MSCs migration [29]. Other striking evidences are provided by using a nuclease-resistant RNA aptamer (Gint4.T) that binds to the extracellular domain of the PDGFR- $\beta$ and impedes the ligand-dependent cross-talk between MSCs and tumor cells both in vitro and in vivo [30-32].

We further investigated the downstream signaling of PDGFR- $\beta$ pathway by using PI3K inhibitor (LY294002) and MAPK inhibitor (PD98059) whereas only LY294002 was associated with a significant decrease of ASCs migration towards breast cancer cells. This is in line with experiments using transgenic mice carrying mutation of PDGFR- $\beta$ which revealed a signaling through PI3K [33]. In addition, a recent study revealed that MSCs stimulate tumor growth and vascularization within colorectal cancer xenograft model in vivo and induce activation of Akt and ERK in endothelial cells, thereby increasing their recruitment and angiogenic potential [34].

Currently there is no doubt that MSCs can have tremendous effects to the microenvironment of tumor regarding angiogenesis, tumor growth and metastasis. It is crucial to understand the tropism 
of MSCs for breast cancer or any other malignant tumor in order to control or target MSCs with a therapeutic approach.

\section{References}

[1] Blocki A, Beyer S, Jung F, Raghunath M. The controversial origin of pericytes during angiogenesis - Implications for cell-based therapeutic angiogenesis and cell-based therapies. Clin Hemorheol Microcirc. 2018;69(1-2):215-32.

[2] Karnoub AE, Dash AB, Vo AP, Sullivan A, Brooks MW, Bell GW, et al. Mesenchymal stem cells within tumour stroma promote breast cancer metastasis. Nature. 2007;449(7162):557-63.

[3] Muehlberg FL, Song Y-H, Krohn A, Pinilla SP, Droll LH, Leng X, et al. Tissue-resident stem cells promote breast cancer growth and metastasis. Carcinogenesis. 2009;30(4):589-97.

[4] Kamat P, Schweizer R, Kaenel P, Salemi S, Calcagni M, Giovanoli P, et al. Human Adipose-Derived Mesenchymal Stromal Cells May Promote Breast Cancer Progression and Metastatic Spread. Plast Reconstr Surg. 2015;136(1):76-84.

[5] Li Z, Xu X, Wang W, Kratz K, Sun X, Zou J, et al. Modulation of the mesenchymal stem cell migration capacity via preconditioning with topographic microstructure. Clin Hemorheol Microcirc. 2017;67(3-4):267-78.

[6] Lejmi E, Perriraz N, Clément S, Morel P, Baertschiger R, Christofilopoulos P, et al. Inflammatory Chemokines MIP-1 $\delta$ and MIP-3 $\alpha$ Are Involved in the Migration of Multipotent Mesenchymal Stromal Cells Induced by Hepatoma Cells. Stem Cells Dev. 2015;24(10):1223-35.

[7] Lourenco S, Teixeira VH, Kalber T, Jose RJ, Floto RA, Janes SM. Macrophage Migration Inhibitory Factor-CXCR4 Is the Dominant Chemotactic Axis in Human Mesenchymal Stem Cell Recruitment to Tumors. The Journal of Immunology. 2015;194(7):3463-74.

[8] Dwyer RM, Potter-Beirne SM, Harrington KA, Lowery AJ, Hennessy E, Murphy JM, et al. Monocyte chemotactic protein-1 secreted by primary breast tumors stimulates migration of mesenchymal stem cells. Clin Cancer Res. 2007;13(17):5020-7.

[9] Johann PD, Müller I. Multipotent Mesenchymal Stromal Cells: Possible Culprits in Solid Tumors? Stem Cells Int. 2015;2015:914632.

[10] Ellis SJ, Pines M, Fairchild MJ, Tanentzapf G. In vivo functional analysis reveals specific roles for the integrin-binding sites of talin. J Cell Sci. 2011;124(11):1844-56.

[11] Zhu W, Huang L, Li Y, Zhang X, Gu J, Yan Y, et al. Exosomes derived from human bone marrow mesenchymal stem cells promote tumor growth in vivo. Cancer Lett. 2012;315(1):28-37.

[12] Lindahl P, Johansson BR, Levéen P, Betsholtz C. Pericyte loss and microaneurysm formation in PDGF-B-deficient mice. Science. 1997;277(5323):242-5.

[13] Soriano P. Abnormal kidney development and hematological disorders in PDGF beta-receptor mutant mice. Genes Dev. 1994;8(16):1888-96.

[14] Enge M, Bjarnegård M, Gerhardt H, Gustafsson E, Kalén M, Asker N, et al. Endothelium-specific platelet-derived growth factor-B ablation mimics diabetic retinopathy. EMBO J. 2002;21(16):4307-16.

[15] Hellström M, Kalén M, Lindahl P, Abramsson A, Betsholtz C. Role of PDGF-B and PDGFR-beta in recruitment of vascular smooth muscle cells and pericytes during embryonic blood vessel formation in the mouse. Development. 1999;126(14):3047-55.

[16] Abramsson A, Lindblom P, Betsholtz C. Endothelial and nonendothelial sources of PDGF-B regulate pericyte recruitment and influence vascular pattern formation in tumors. J Clin Invest. 2003;112(8):1142-51.

[17] Furuhashi M, Sjöblom T, Abramsson A, Ellingsen J, Micke P, Li H, et al. Platelet-derived growth factor production by B16 melanoma cells leads to increased pericyte abundance in tumors and an associated increase in tumor growth rate. Cancer Res. 2004;64(8):2725-33.

[18] McCarty MF, Somcio RJ, Stoeltzing O, Wey J, Fan F, Liu W, et al. Overexpression of PDGF-BB decreases colorectal and pancreatic cancer growth by increasing tumor pericyte content. J Clin Invest. 2007;117(8):2114-22.

[19] Jotzu C, Alt E, Welte G, Li J, Hennessy BT, Devarajan E, et al. Adipose tissue-derived stem cells differentiate into carcinoma-associated fibroblast-like cells under the influence of tumor-derived factors. Anal Cell Pathol (Amst). 2010;33(2):61-79.

[20] Amos PJ, Shang H, Bailey AM, Taylor A, Katz AJ, Peirce SM. IFATS collection: The role of human adiposederived stromal cells in inflammatory microvascular remodeling and evidence of a perivascular phenotype. Stem Cells. 2008;26(10):2682-90.

[21] Pinilla S, Alt E, Abdul Khalek FJ, Jotzu C, Muehlberg F, Beckmann C, et al. Tissue resident stem cells produce CCL5 under the influence of cancer cells and thereby promote breast cancer cell invasion. Cancer Lett. 2009;284(1):80-5. 
[22] Gehmert S, Gehmert S, Prantl L, Vykoukal J, Alt E, Song Y-H. Breast cancer cells attract the migration of adipose tissue-derived stem cells via the PDGF-BB/PDGFR-beta signaling pathway. Biochem Biophys Res Commun. 2010;398(3):601-5.

[23] Gehmert S, Wenzel C, Loibl M, Brockhoff G, Huber M, Krutsch W, et al. Adipose tissue-derived stem cell secreted IGF-1 protects myoblasts from the negative effect of myostatin. Biomed Res Int. 2014;2014:129048.

[24] Abramoff MD, Magalhaes PJ, Ram SJ. Image processing with ImageJ. Biophotonics International. $2004 ; 11(7): 36-42$.

[25] Gehmert S, Gehmert S, Hidayat M, Sultan M, Berner A, Klein S, et al. Angiogenesis: The role of PDGF-BB on adipose-tissue derived stem cells (ASCs). Clin Hemorheol Microcirc. 2011;48(1):5-13.

[26] Nwabo Kamdje AH, Kamga PT, Simo RT, Vecchio L, Seke Etet PF, Muller JM, et al. Mesenchymal stromal cells' role in tumor microenvironment: Involvement of signaling pathways. Cancer Biol Med. 2017;14(2):129-41.

[27] Klopp AH, Spaeth EL, Dembinski JL, Woodward WA, Munshi A, Meyn RE, et al. Tumor irradiation increases the recruitment of circulating mesenchymal stem cells into the tumor microenvironment. Cancer Res. 2007;67(24):1168795.

[28] Hata N, Shinojima N, Gumin J, Yong R, Marini F, Andreeff M, et al. PDGF-BB Mediates the Tropism of Human Mesenchymal Stem Cells for Malignant Gliomas. Neurosurgery. 2010;66(1):144-57.

[29] Fiedler J, Etzel N, Brenner RE. To go or not to go: Migration of human mesenchymal progenitor cells stimulated by isoforms of PDGF. J Cell Biochem. 2004;93(5):990-8.

[30] Camorani S, Hill BS, Fontanella R, Greco A, Gramanzini M, Auletta L, et al. Inhibition of Bone Marrow-Derived Mesenchymal Stem Cells Homing Towards Triple-Negative Breast Cancer Microenvironment Using an Anti-PDGFR $\beta$ Aptamer. Theranostics. 2017;7(14):3595-607.

[31] Camorani S, Esposito CL, Rienzo A, Catuogno S, Iaboni M, Condorelli G, et al. Inhibition of receptor signaling and of glioblastoma-derived tumor growth by a novel PDGFR $\beta$ aptamer. Mol Ther. 2014;22(4):828-41.

[32] Monaco I, Camorani S, Colecchia D, Locatelli E, Calandro P, Oudin A, et al. Aptamer Functionalization of Nanosystems for Glioblastoma Targeting through the Blood-Brain Barrier. J Med Chem. 2017;60(10):4510-6.

[33] Rodt SA, Ahlén K, Berg A, Rubin K, Reed RK. A novel physiological function for platelet-derived growth factor-BB in rat dermis. J Physiol. 1996;495(Pt 1):193-200.

[34] Huang W-H, Chang M-C, Tsai K-S, Hung M-C, Chen H-L, Hung S-C. Mesenchymal stem cells promote growth and angiogenesis of tumors in mice. Oncogene. 2013;32(37):4343-54. 


\section{ERKLÄRUNG ZUM PROMOTIONSVERFAHREN}

nach $\S 3$ Abs. 3 und 4 der Promotionsordnung der Fakultät für Medizin der Universität Regensburg

\begin{tabular}{|c|c|}
\hline Name: & Salha \\
\hline Vorname: & Sonia \\
\hline geb. am: & 26.09.1977 \\
\hline in: & Darmstac \\
\hline
\end{tabular}

Ich erkläre,

- dass ich den Doktorgrad der Medizin nicht schon an einer Hochschule der Bundesrepublik Deutschland erworben habe

- das ich nicht an anderer Stelle zu einem Promotionsverfahren zum Erwerb des medizinischen Doktorgrades zugelassen bin

- dass ich die medizinische Doktorprüfung nicht schon an einer Hochschule der Bundesrepublik Deutschland endgültig nicht bestanden habe

Außerdem erkläre ich,

- dass mir keine Tatsachen bekannt sind, die mich zur Führung eines akademischen Grades im Sinne des Gesetzes über die Führung akademischer Grade unwürdig erscheinen lassen

- dass ich die vorliegende Arbeit ohne unzulässige Hilfe Dritter und ohne Benutzung anderer als der angegebenen Hilfsmittel angefertigt habe. Die aus anderen Quellen direkt oder indirekt übernommenen Daten und Konzepte sind unter Angabe der Quelle gekennzeichnet. Insbesondere habe ich nicht die entgeltliche Hilfe von Vermittlungs- bzw. Beratungsdiensten (Promotionsberater oder andere Personen) in Anspruch genommen. Niemand hat von mir unmittelbar oder mittelbar geldwerte Leistungen für Arbeit erhalten, die im Zusammenhang mit dem Inhalt der vorgelegten Dissertation stehen. Die Arbeit wurde bisher weder im In- noch im Ausland in gleicher oder ähnlicher Form einer anderen Prüfungsbehörde vorgelegt. 


\section{Curriculum Vitae \\ Sonia Salha}

\section{Persönliche Daten}

geboren am

Geburtsort

Familienstand

Nationalität
26. September 1977

Darmstadt

ledig

deutsch

\section{Berufspraxis}

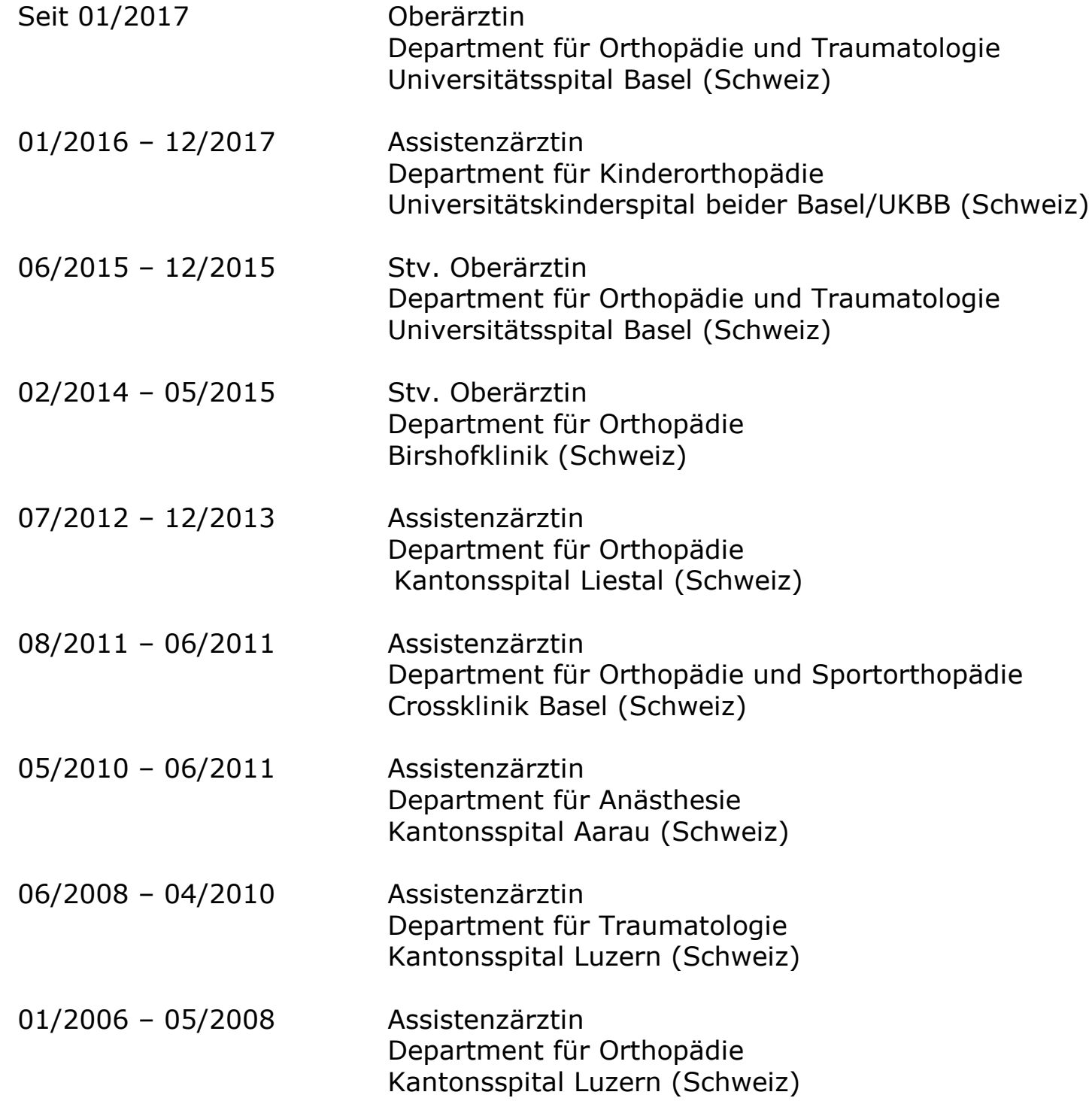




\section{Akademische Ausbildung}

02.12 .2017

10.06.2017

07.11 .2015

16.12 .2005

$04 / 1998-11 / 2005$
Facharzt für Orthopädische Chirurgie und Traumatologie FMH Facharzt/Schweiz

schriftliche Prüfung Orthopädie/FMH (Schweiz)

Basisexamen FMH (Schweiz)

\section{Approbation}

Rheinland-Pfalz

Studium der Humanmedizin

Johannes Gutenberg-Universität Mainz

\section{Schulbildung/FSJ}

1997

1996
Freiwilliges Soziales Jahr, Wolfgang Winkler Haus

Entgiftungs- und Übergangseinrichtung für Drogenabhängige

\section{Mitgliedschaften}

Internationales Rotes Kreuz

Ärzte ohne Grenzen

Deutscher Ärztinnenbund

Swiss Orthopaedics

FMH

VSAO

\section{Fremdsprachen}

Englisch (verhandlungssicher)

Arabisch (verhandlungssicher)

Französisch (Grundkenntnisse)

Basel, den 23.03.2019 